\title{
DOEIPC/92542 -.T10
}

Robotic Weld Overlay Coatings

For Erosion Control

Progress Report Prepared For U.S. Department of Energy under Grant No. DE-FG22-92 PS92542

Quarterly Technical Progress Report For The Period January 1995 through March 1995

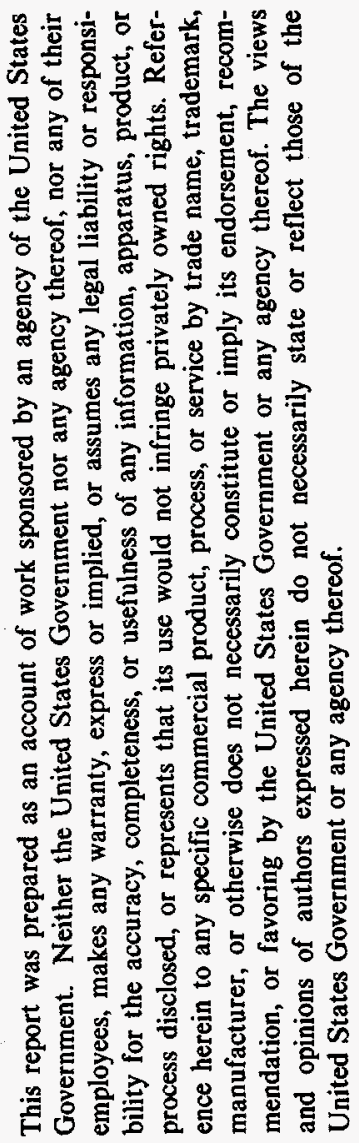

$$
\text { B.F. Levin }
$$

J.N. Dupont

and

A.R. Marder

Energy Research Center

117 ATLSS Drive

Lehigh University

Bethlehem PA 18015

April 25, 1995

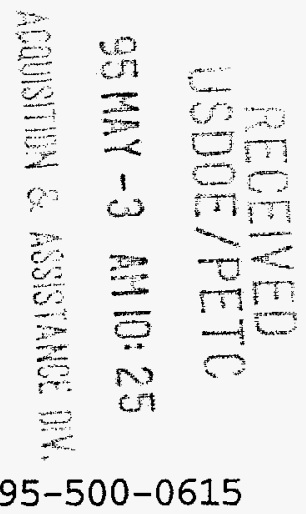




\section{DISCLAIMER}

Portions of this document may be illegible in electronic image products. Images are produced from the best available original document. 


\section{EXECUTIVE SUMMARY}

Research is presently being conducted to develop a criteria for selecting weld overlay coatings for erosion mitigation in Circulated Fluidized Beds. Initially, eleven weld overlay alloys were selected for erosion testing based upon a literature review. All eleven coatings were deposited on 1018 steel substrates using the plasma arc welding process [1]. Ten samples from each coating were prepared for erosion testing. The coating deposition and sample preparation procedures were described in the second quarterly report [2]. All selected coatings were erosion tested at $400^{\circ} \mathrm{C}$ and their erosion resistance was evaluated by determining the steady state erosion rate. In addition, the microstructure of each coating was characterized before and after the erosion tests. The results of the tests are discussed in the third quarterly report [3]. No correlations were found between room temperature hardness of the weld overlay coatings and their erosion resistance at elevated temperature. It was suggested that weld overlay mechanical properties such as fracture strength, toughness and work hardening rates may contribute to their erosion resistance. During the previous two quarters the microhardness tests were performed on the eroded samples in order to determine the size of the work hardened zone and the change in the coating hardness due to erosion. As a result of these measurements it was established that one group of coatings deformed plastically, while another did not $[4,5]$. Therefore, these two group of coatings might exhibit different erosion mechanisms. In addition, measurements of the weld overlay microhardness at $400^{\circ} \mathrm{C}$ were made [6]. The coatings microhardness at $400^{\circ} \mathrm{C}$ was plotted versus their volumetric erosion rates. Also, the erosion tests were performed for the Inconel-625, 316L SS, and Iron-Aluminide wrought alloys in order to compare their erosion behavior with 
similar weld overlays. The results of microhardness profile measurements for all weld overlay coatings were analyzed and presented in the previous quarterly report [7]. During the last two quarters tensile tests were performed at $400^{\circ} \mathrm{C}$ for the Ultimet, Inconel-625, 316L SS, $\mathrm{C}-22$, and Stellite- 6 wrought alloys. Also, the erosion tests for these materials at $400^{\circ} \mathrm{C}$ were completed. The results of mechanical and erosion tests are used to correlate mechanical properties of selected wrought alloys such as tensile toughness, ductility, strain hardening coefficient and yield strength to their erosion resistance at $400^{\circ} \mathrm{C}$. Preliminary results of correlations between erosion resistance of wrought alloys at $400^{\circ} \mathrm{C}$ and their mechanical properties are presented in this progress report.

\section{INTRODUCTION}

The erosion of materials by the impact of solid particles has received increasing attention during the past twenty years. Recently, research has been initiated with the event of advanced coal conversion processes in which erosion plays an important role. The resulting damage, termed Solid Particle Erosion (SPE), is of concern primarily because of the significantly increased operating costs which result in material failures. Reduced power plant efficiency due to solid particle erosion of boiler tubes and waterwalls has led to various methods to combat SPE. One method is to apply coatings to the components subjected to erosive environments. Protective weld overlay coatings are particularly advantageous in terms of coating quality. The weld overlay coatings are essentially immune to spallation due to a strong metallurgical bond with the substrate material. By using powder mixtures, multiple alloys can be mixed in order to achieve the best performance in an erosive environment. 
However, a review of the literature revealed a lack of information on weld overlay coating performance in erosive environments which makes the selection of weld overlay alloys a difficult task [1]. The objective of this project is to determine the effects of weld overlay coating composition, microstructure and mechanical properties on their erosion resistance. These results will lead to a better understanding of erosion mitigation in CFB's.

\section{EXPERIMENTAL PROCEDURE}

\section{III.1. Erosion and Tensile Tests}

In order to determine the effect of mechanical properties on erosion resistance at elevated temperature $\left(400^{\circ} \mathrm{C}\right)$, tensile tests and erosion tests $\left(\mathrm{T}=400^{\circ} \mathrm{C}\right.$ and $90^{\circ}$ erodent impact angle) were performed for Ultimet, Inconel-625, C-22, 316L SS, and Stellite-6 wrought materials. The experimental procedure and results of the tensile tests were reported in the previous quarterly report [8]. The erosion tests procedure was described earlier [3].

\section{RESULTS}

The erosion kinetics for the tested wrought alloys are shown in Figure 1. In this figure weight loss is plotted against the erosion time. The volumetric steady state erosion rates were determined by dividing weight loss rate by the alloy density and presented in Table I. It can be seen that Stellite- 6 alloy showed the highest erosion rate and Inconel-625 alloy showed the lowest erosion rate.

It was indicated in the previous quarterly reports [5-7], that tensile toughness (area under the true stress-strain diagram) may be an important material property that contributes to the 
erosion resistance. Tensile toughness represents the amount of energy that a material absorbs before fracture. As a result of this project it was established that the ability of the ductile weld overlay coatings to absorb impact energy through plastic deformation improves their erosion resistance $[6,7]$. The ability to absorb impact energy was estimated by calculated the area under the microhardness profile curve after erosion. Considering the similarities between stress-strain curves and microhardness profile curves $[6,7]$, tensile toughness may contribute to the erosion resistance of ductile materials. The effect of tensile toughness on the erosion resistance of wrought alloy is shown in Figure 2. It can be seen that alloys with the lowest tensile toughness (Stellite-6) showed the lowest erosion resistance while materials with significantly higher tensile toughness (Ultimet, Inconel-625, and C-22) showed much higher erosion resistance. Although a trend of increase in erosion resistance with increase in tensile toughness is observed, the Inconel-625 alloy that has a lower toughness than Ultimet and C22 alloys showed the best erosion resistance. It should be emphasized that tensile toughness was determined from low strain rate tensile tests (about $10^{-2} \mathrm{~s}^{-1}$ ), while erosion process involve strain rates in the order of $10^{3}-10^{5} \mathrm{~s}^{-1}$. As a result of this effect, if a material is strain rate sensitive the toughness that was measured from the tensile test might be different from the toughness during erosion. The area under the microhardness profile curves will be calculated in order to observe correlations with the erosion resistance for tested wrought alloys. Investigation of the relationships between the mechanical properties of the wrought alloys that were obtained from the tensile tests and the microhardness profile for these alloys after erosion are in progress and will be presented in the final report. 


\section{REFERENCES}

1. Levin, B.F., Dupont, J.N., and Marder,A.R., Quarterly Technical Progress Report For The Period January 1993 through March 1993, Lehigh University, Energy Research Center, 93-500-9-15.

2. Levin, B.F., Dupont, J.N., and Marder, A.R., Quarterly Technical Progress Report For The Period April 1993 through June 1993, Lehigh University, Energy Research Center, 93-500-15-27.

3. Levin, B.F., Dupont, J.N., and Marder, A.R., Quarterly Technical Progress Report For The Period October July 1993 through September 1993, Lehigh University, Energy Research Center, 93-500-22-40.

4. Levin, B.F., Dupont, J.N., and Marder, A.R., Quarterly Technical Progress Report For The Period October 1993 through December 1993, Lehigh University, Energy Research Center, 94-500-03-04.

5. Levin, B.F., Dupont, J.N., and Marder, A.R., Quarterly Technical Progress Report For The Period January 1994 through March 1994, Lehigh University, Energy Research Center.

6. Levin, B.F., Dupont, J.N., and Marder, A.R., Quarterly Technical Progress Report For The Period April 1994 through June 1994, Lehigh University, Energy Research Center.

7. Levin, B.F., Dupont, J.N., and Marder, A.R., Quarterly Technical Progress Report For The Period July 1994 through September 1994, Lehigh University, Energy Research Center, 94-500-2544.

8. Levin, B.F., Dupont, J.N., and Marder, A.R., Quarterly Technical Progress Report For The Period October 1994 through December 1994, Lehigh University, Energy Research Center, 95-500-0206. 


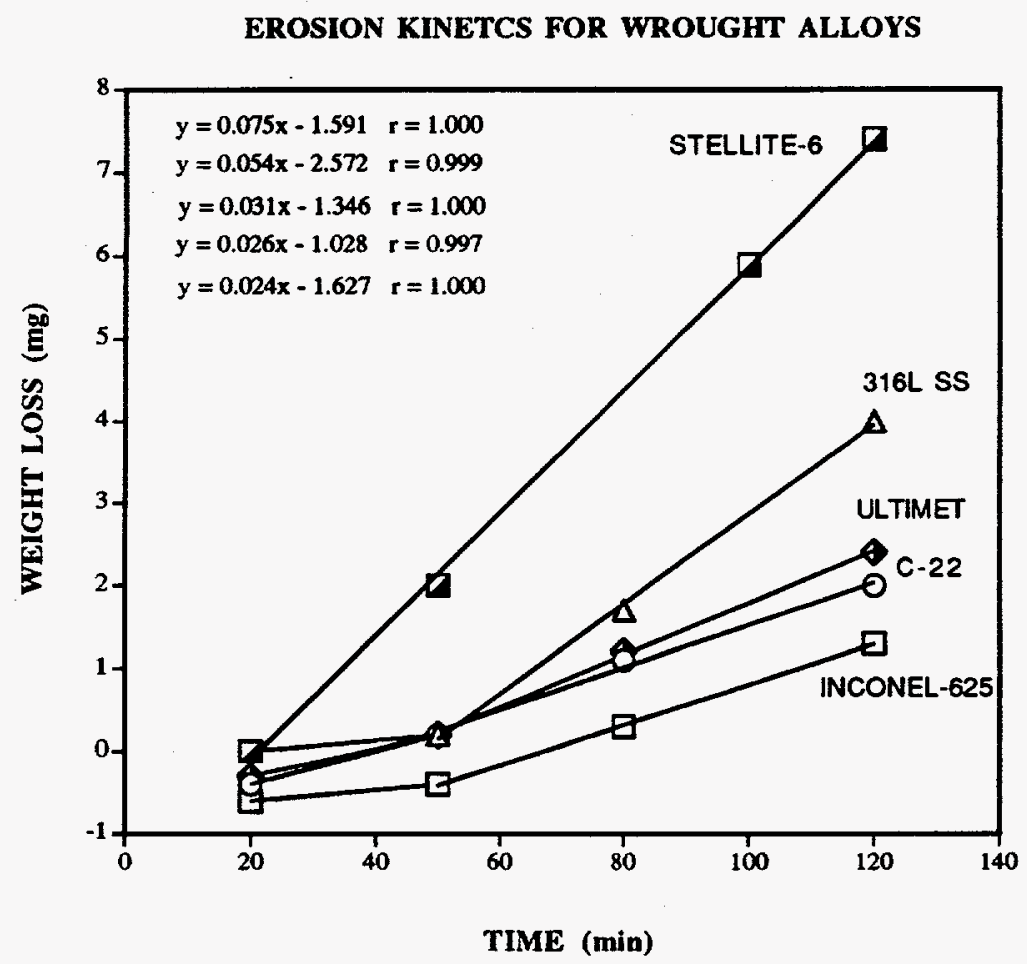

Figure 1. Erosion kinetics for the tested wrought alloys.

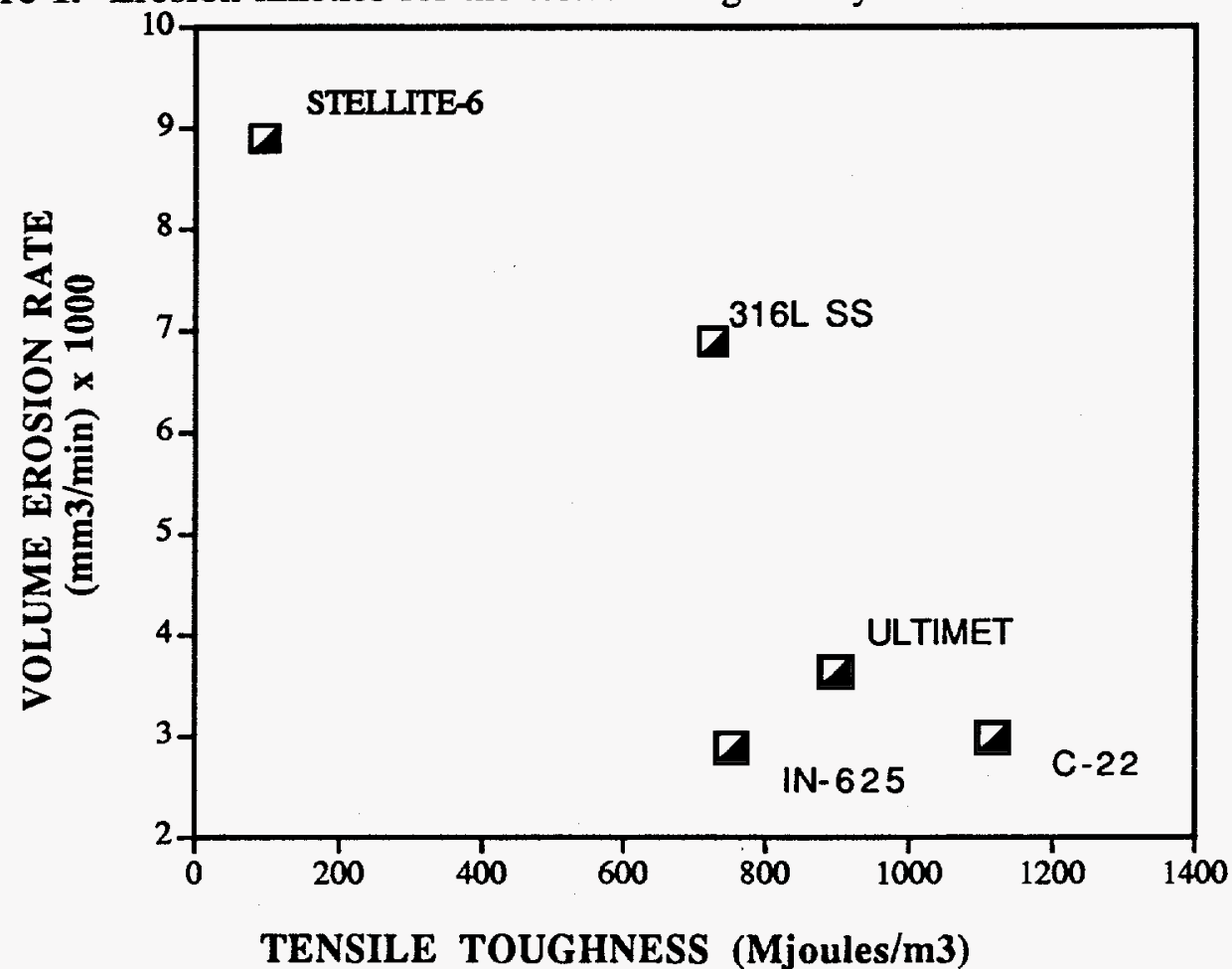

Figure 2. Effect of tensile toughness (from the tensile tests) on volume erosion rate of the tested wrought alloys. 
Table I. Relative erosion ranking of the wrought alloys $\left(90^{\circ}\right.$ particle impact angle, $\mathrm{Al}_{2} \mathrm{O}_{3}$ erodent, $40 \mathrm{~m} / \mathrm{sec}$ velocity).

\begin{tabular}{||c|c|}
\hline WROUGHT ALLOYS & EROSION RATE $\left(\mathbf{m m}^{3} / \mathbf{m i n}\right) \mathbf{x} \mathbf{1 0}^{\mathbf{3}}$ \\
\hline STELLITE-6 & 8.9 \\
316L SS & 6.8 \\
ULTIMET & 3.6 \\
C-22 & 3.0 \\
INCONEL-625 & 2.9 \\
\hline
\end{tabular}

